\title{
Exploitation of distant Antarctic waters and close shelf-break waters by white-chinned petrels rearing chicks
}

\author{
Antoine Catard, Henri Weimerskirch*, Yves Cherel \\ Centre d'Etudes Biologiques de Chizé, UPR 1934 du Centre National de la Recherche Scientifique, \\ 79360 Villiers-en-Bois, France
}

\begin{abstract}
The foraging ecology of white-chinned petrels Procellaria aequinoctialis rearing chicks was examined at the Crozet Islands in the Southern Ocean, based on satellite tracking, diet and provisioning studies. White-chinned petrels from the Crozet Islands exploit a wide variety of marine environments ranging from sub-tropical waters to the limit of pack-ice at the edge of the Antarctic continent. This capability was made possible by the use of a 2 -fold strategy whereby adults exploit alternatively distant oceanic waters and neritic slope waters in the vicinity of the breeding grounds. On average the birds conducted a long foraging trip followed by 2.2 short trips. During trips of long duration over oceanic waters, birds tended to commute mainly to cold, deep Antarctic waters where most foraging activity took place. They commuted from and returned to Crozet at high speeds (mean 31 and $34 \mathrm{~km} \mathrm{~h}^{-1}$ respectively) with a mean foraging range of $1868 \mathrm{~km}$ (maximum $2421 \mathrm{~km}$ ). In Antarctic waters, the white-chinned petrel appears to feed mainly on pelagic fishes and on Antarctic krill Euphausia superba and concentrates its efforts in waters with sea-surface temperatures of $2^{\circ} \mathrm{C}$. During short trips the birds commuted to the Crozet shelf break, where they fed mainly on fish. Diet samples delivered to chicks after short trips indicate that adults relied at least in part on food made available by longliners as baits and discards. Despite its small size compared to albatrosses, the white-chinned petrel from Crozet appears to be a particularly wide-ranging species and an opportunistic feeder in terms of the marine environment exploited, which explains its wide distribution in the Southern Ocean. This study highlights the particular importance of Antarctic waters for this sub-Antarctic species during the chick-rearing period, i.e. in summer when the retreat of the pack-ice makes abundant resources such as Antarctic krill available.
\end{abstract}

KEY WORDS: Antarctic krill - Diet - Feeding ecology - Foraging strategy - Procellaria aequinoctialis . Satellite tracking $\cdot$ Long-line fishery

\section{INTRODUCTION}

Seabirds are top predators that play a significant role in the marine environment and can be convenient indicators of the distribution and availability of marine resources (Cherel \& Weimerskirch 1995, Rodhouse et al. 1996, Croxall et al. 1999). They inhabit a highly heterogeneous environment, with their distribution being affected by both physical and biological features of the ocean (Hunt 1991) and being related to scale-dependent processes (Hunt \& Schneider 1987). They are noticeably abundant in zones of enhanced production such as frontal zones and shelf slopes (Ashmole 1971,

\footnotetext{
•Corresponding author. E-mail: henriw@cebc.cnrs.fr
}

Abrams 1985, Schneider 1990, Hunt 1991). In the Southern Ocean, one of the main constraints for seabirds is the discrepancy between the vastness of the marine environment and the scarcity of breeding grounds. Islands are rare and, therefore, are usually home to large populations of seabirds that have developed specific adaptations and ecological segregation for exploiting their environment (Croxall \& Prince 1980, Ricklefs 1990). Pelagic species of albatrosses and petrels dominate the seabird community in the Southern Ocean. The major constraint for these pelagic seabirds is breeding, when the birds have to provision their offspring and themselves from more or less distant and patchy resources (Ashmole 1971, Ricklefs 1990). 
In the Southern Ocean, the tendency for several species to concentrate on specific and predictable areas such as the Polar Frontal Zone (between the SubAntarctic Front and the Polar Front), has been established (Rodhouse et al. 1996, Guinet et al. 1997. Hull et al. 1997, Prince et al. 1998). During breeding the distance between these highly productive zones and the nesting grounds is likely to limit the ability of birds to provision their offspring at a sufficient rate. Pelagic seabirds have therefore developed specific breeding strategies (Ricklefs 1990) as well as foraging adaptations such as the use of a 2 -fold strategy (Weimerskirch et al. 1994, 1998a). How pelagic seabirds exploit their vast surrounding marine environment remains logistically difficult to study. The use of at-sea surveys allows investigation of the distribution of seabirds in relation to marine-environmental features (Schneider 1990, Hunt 1991, Pakhomov \& McQuaid 1996). However it is impossible to determine the breeding status of seabirds at sea, to observe their individual behaviour and often to determine their prey based on simple observations (Brown 1980. Hunt \& Schneider 1987). Satellite tracking has considerably advanced our understanding of seabirds' relationships with the marine environment (Jouventin \& Weimerskirch 1990, Weimerskirch 1998a), but was until recently limited to the albatrosses, due to their large size. The reduction in size of satellite transmitters now enables tracking of mediumsized seabirds

The white-chinned petrel Procellaria aequinoctialis is an abundant species in the Southern Ocean. It is found in summer from tropical waters to the edge of the Antarctic continent, while breeding grounds are found on sub-Antarctic islands in the middle of this wide range (Marchant \& Higgins 1990). P. aequinoctialis is the largest burrowing petrel, with a mass of $1.2 \mathrm{~kg}$ and a wing span of $1.5 \mathrm{~m}$, and is known to be an adaptive and ubiquitous species. The breeding biology and the diet of white-chinned petrels have been studied at several locations, including Crozet (Mougin 1970, Hall 1987, Jackson 1988, Cooper et al. 1992, Ridoux 1994. Croxall et al. 1995, Berrow \& Croxall 1999), and recent results are available regarding the foraging zones of the species (Catard \& Weimerskirch 1999, Weimerskirch et al. 1999b, Berrow et al. in press). However, no one has extensively explored the foraging and provisioning strategy of this species in relation to the marine environment. At the Crozet Islands in the Indian Ocean, previous dietary information (Ridoux 1994) suggests that breeding white-chinned petrels could be wide-ranging, since Antarctic krill Euphausia superba occurred in some diet samples. However, previous observations of remote white-chinned petrels during the breeding season were invariably considered to be of non-breeders (Bierman \& Voos 1950, Rand 1963,
Woehler et al. 1990). The Crozet population is estimated at 30000 pairs (Jouventin et al. 1988). Unlike other breeding grounds of the species, such as South Georgia and Kerguelen that are surrounded by an extensive shelf, at the Crozet Islands the surrounding shelf is small. Therefore, the surrounding shelf marine resources may be limited at Crozet. Recently an increasing fishery, including numerous unregulated fishing vessels, started to operate on the Crozet shelf. Since white-chinned petrels are attracted to fishing vessels, with long-liners causing high mortality rates of this species in the Indian Ocean (Cherel et al. 1996, Barnes et al. 1997), it is possible that the distribution of the species may be affected by the presence of a fishery in the vicinity of the breeding grounds.

Our aims were to investigate how white-chinned petrels breeding at the Crozet Islands exploit the marine environment in relation to oceanographic features such as bathymetry or sea-surface temperatures, and whether there is any indication of a reliance of this bird on fishing vessels. To do so, we simultaneously studied the locations of foraging birds at sea by means of satellite tracking and individual provisioning strategies and diet on land.

\section{MATERIALS AND METHODS}

Study site and birds. The field study was carried out between 26 January and 22 February 1997 on lle de la Possession $\left(46^{\circ} 25^{\prime} \mathrm{S}, 51^{\circ} 45^{\prime} \mathrm{E}\right)$, Crozet Islands, located in the southwestern Indian Ocean. A study colony was established in November 1995. When the nest chamber could not be reached by hand, an observation window was dug above the nest chamber and covered with a wooden board. To limit the risk of chick mortality associated with rats Rattus rattus, and thus to increase breeding success (T. Micol unpubl.), the rat population was trapped and poisoned starting 2 wk before and continuing at $2 \mathrm{wk}$ intervals throughout the breeding period. In 1995-96, birds from 57 pairs of white-chinned petrels were banded; within each pair, 1 bird had a plastic band on the left leg and a metal band on the right leg; this banding order was reversed for its mate to facilitate identification of individual birds without handling them. Petrels were measured (culmen, maxillary unguis and wing lengths, and body weight), and sexed, with the male being considered to be larger than the female within a pair (Murphy 1936) A discriminant analysis was used to sex birds whose mate had not been measured.

During the chick-rearing period, 21 burrows of the study colony were monitored for $3 \mathrm{wk}$, between 26 January and 15 February 1997. Sticks were placed at the entrance of each burrow, so that a visit by an adult 
could be detected by displacement of the sticks. Burrows were inspected continuously, every half-hour, day and night throughout the entire study period. Chicks were weighed to the nearest gram twice a day, at 08:00 and 21:00 h (local time: GMT + 5), using an Ohaus ${ }^{\circledast}$ electronic balance or Pesola ${ }^{\circledast}$ spring balance. As soon as an adult's visit to its chick was detected, the bird was identified from the observation window, and its time of arrival was recorded. After the departure of the adult, the chick was weighed, and meal size was calculated as the difference between the previous weighing and the mass recorded after the feeding event. When 2 parents visited the chick simultaneously, the double feed was not used in our analysis. The body condition of chicks was defined as the residual from the linear regression of body mass upon date. At the time of the study, the chicks were in a phase of linear growth in mass (Mougin 1970).

Satellite tracking. The foraging trips of adult whitechinned petrels were monitored using the Argos satellite tracking system (Fancy et al. 1988). The transmitters (Microwave 100) weighed $30 \mathrm{~g}$, which corresponded to 1.6 to $2.9 \%$ of the bird body mass (range: 1.03 to $1.87 \mathrm{~kg}$ ). The dimensions of the platform transmitting terminals (PTTs) were $65 \mathrm{~mm}$ long, $16 \mathrm{~mm}$ wide and $15 \mathrm{~mm}$ high, with a $215 \mathrm{~mm}$ long aerial. They were attached directly to the back feathers, using adhesive tape and epoxy resin to avoid loss during diving, as white-chinned petrels are known to be efficient divers (Huin 1994). The transmission interval was $90 \mathrm{~s}$. Between 27 January and 22 February 1997, 6 transmit- ters were deployed simultaneously and were recovered during a feeding visit after 1, 2 or 3 consecutive foraging trips of adult birds (Table 1). No transmission failure and no loss of transmitters occurred during the study period. Data were analysed using ELSA software (CLS Argos, Toulouse, France) and custom-made software. All classes of location accuracy provided by the Argos system were used. Only locations that were implausible (flight speed $>90 \mathrm{~km} \mathrm{~h}^{-1}$ ) were excluded. Since the number of locations recorded per hour was not uniform, we analysed the time spent at sea (rather than the number of locations recorded) in relation to environmental variables using a custom-made program (Diomedea 1.07) that interpolates bathymetric features and sea-surface temperatures in relation to satellite locations. Bathymetric data were collected from the General Bathymetric Chart of the Oceans (GEBCO 1997) and weekly sea-surface temperature data from Integrated Global Ocean Services System (IGOSS, Reynolds \& Smith 1994).

Food analysis. Food samples were collected from chicks to avoid disturbance and risk of burrow desertion by handled adult birds. They were obtained using the 'water off-loading technique' (Wilson 1984) after a feeding visit of the adult. Generally only 1 meal was collected per individual chick, except in the case of 4 chicks which were artificially fed with fish flesh and cod liver oil after a second manipulation. Twenty-three food samples corresponding to trips of known duration were collected, 10 after short trips and 13 after long trips (including 5 satellite-tracked foraging trips) per-

Table 1. Procellaria aequinoctialis. Details of 14 foraging trips performed by white-chinned petrels rearing chicks at the Crozet Islands, southwestern Indian Ocean. "The first number following the $\mathrm{C}$ refers to the PTT/bird number, and the second number $(1,2$ or 3$)$ refers to the order of the foraging trip

\begin{tabular}{|c|c|c|c|c|c|c|c|c|c|c|}
\hline & Track ${ }^{\circ}$ & Sex & $\begin{array}{l}\text { Date of } \\
\text { departure } \\
(\mathrm{d} / \mathrm{mo} / \mathrm{yr})\end{array}$ & $\begin{array}{l}\text { Date of } \\
\text { return } \\
(\mathrm{d} / \mathrm{mo} / \mathrm{yr})\end{array}$ & $\begin{array}{l}\text { Duration } \\
\text { (d) }\end{array}$ & $\begin{array}{l}\text { Total distance } \\
\text { covered } \\
(\mathrm{km})\end{array}$ & $\begin{array}{l}\text { Maximum } \\
\text { range } \\
(\mathrm{km})\end{array}$ & $\begin{array}{l}\text { Outward } \\
\text { velocity } \\
\left(\mathrm{km} \mathrm{h}^{-1}\right)\end{array}$ & $\begin{array}{c}\text { Return } \\
\text { velocity } \\
\left(\mathrm{km} \mathrm{h}^{-1}\right)\end{array}$ & $\begin{array}{c}\text { Foraging } \\
\text { velocity } \\
\left(\mathrm{km} \mathrm{h}^{-1}\right)\end{array}$ \\
\hline Long & C-69-1 & M & $27 / 1 / 97$ & $07 / 2 / 97$ & 11.0 & 6785 & 2019 & 34 & 26 & 25 \\
\hline trips & C-69-3 & $M$ & $09 / 2 / 97$ & $22 / 2 / 97$ & 12.9 & 7792 & 1903 & 39 & 29 & 24 \\
\hline \multirow[t]{7}{*}{$(\mathrm{LT})$} & C-72-1 & M & $29 / 1 / 97$ & $06 / 2 / 97$ & 7.7 & 5377 & 1900 & 33 & 49 & 20 \\
\hline & C-73-1 & $M$ & $30 / 1 / 97$ & $06 / 2 / 97$ & 6.6 & 4890 & 1843 & 22 & 38 & 21 \\
\hline & C-70-1 & $\mathrm{F}$ & $27 / 1 / 97$ & $06 / 2 / 97$ & 10.1 & 724.5 & 2421 & 31 & 27 & 22 \\
\hline & $C-70-3$ & $\mathrm{~F}$ & $07 / 2 / 97$ & $17 / 2 / 97$ & 9.7 & 6015 & 2343 & 35 & 29 & 27 \\
\hline & C-71-1 & F & $30 / 1 / 97$ & $01 / 2 / 97$ & 2.8 & 2095 & 826 & 27 & 35 & - \\
\hline & $C-71-2$ & $\mathrm{~F}$ & $01 / 2 / 97$ & $07 / 2 / 97$ & 5.6 & 4167 & 1671 & 35 & 47 & 16 \\
\hline & $C-74-1$ & F & $01 / 2 / 97$ & $11 / 2 / 97$ & 10.1 & 4961 & 1887 & 20 & 28 & 20 \\
\hline Mean & & & & & $8.5 \pm 3.1$ & $5481 \pm 1741$ & $1868 \pm 459$ & $31 \pm 6$ & $34 \pm 9$ & $25 \pm 6$ \\
\hline Short & $C-72-2$ & $M$ & $06 / 2 / 97$ & $06 / 2 / 97$ & 0.3 & 33 & 12 & & & 5 \\
\hline trips & $C-72-3$ & M & $06 / 2 / 97$ & $09 / 2 / 97$ & 2.4 & 391 & 115 & & & 9 \\
\hline \multirow[t]{3}{*}{$(\mathrm{ST})$} & $C-73-2$ & $M$ & $06 / 2 / 97$ & $07 / 2 / 97$ & 0.9 & 161 & 50 & & & 11 \\
\hline & C-69-2 & $M$ & $07 / 2 / 97$ & $09 / 2 / 97$ & 1.7 & 238 & 74 & & & 6 \\
\hline & $C-70-2$ & $F$ & $06 / 2 / 97$ & $07 / 2 / 97$ & 0.9 & 157 & 62 & & & 1.0 \\
\hline Mean & & & & & $1.2 \pm 0.8$ & $196 \pm 131$ & $62 \pm 37$ & & & $8 \pm 3$ \\
\hline
\end{tabular}


formed by adult birds (for definition of short and long trips, see 'Results'). Stomach contents were returned deep frozen $\left(-20^{\circ} \mathrm{C}\right)$ to the laboratory in Chize, France, for subsequent analysis. There, each sample was thawed and drained by gravity to separate oil and water from the solid fraction. The volume of oil was then measured in a graduated tube. In the solid fraction, accumulated items (mainly squid beaks) were discarded, while fresh remains were divided into broad prey classes (fish, cephalopod, crustaceans and salps) which were weighed to calculate their proportion by mass in the diet. Each prey item was counted and identified to the lowest possible taxon, using published keys (Barnard 1961, Pequegnat 1965, Whitehead 1985. Clarke 1986, Baker et al. 1990, Smale et al. 1995) and our own reference collection.

Statistics. Data were analysed using SYSTAT 7.0 (Wilkinson 1997).

\section{RESULTS}

\section{Foraging zones and tracks}

A total of 14 foraging trips was recorded from the 6 birds rearing chicks equipped with satellite transmitters (Table 1). Frequency distribution of the maximum

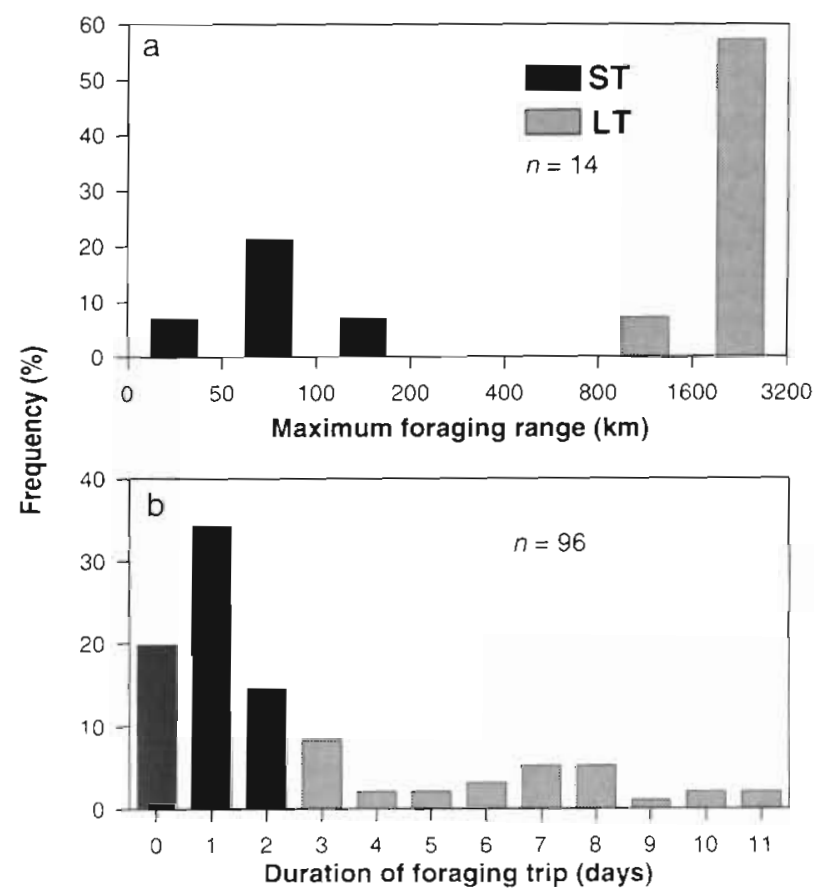

Fig. 1. Procellana dequinoctialis. Frequency distribution of (a) maximum foraging range determined by satellite tracking, and (b) duration of foraging trips determined by abservation at burrows. ST: short trip; LI: long trip

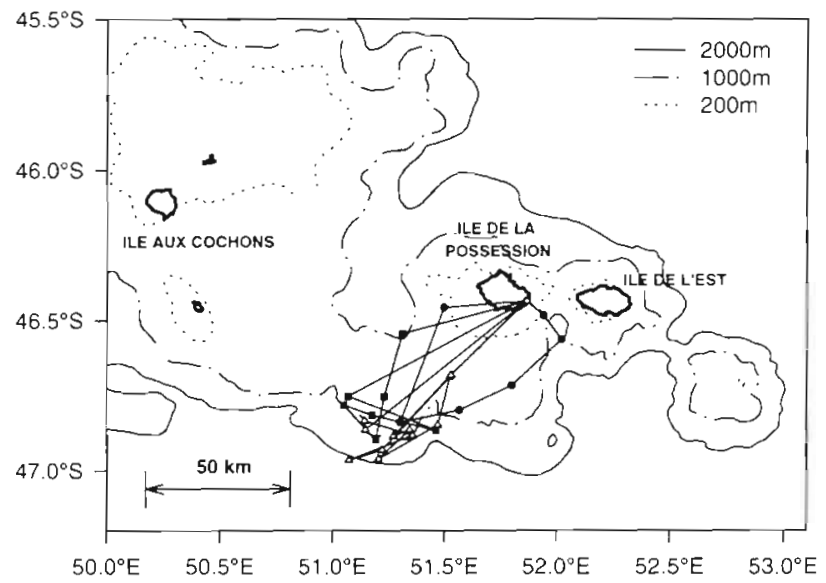

Fig. 2. Procellaria aequinoctialis. Detailed tracks of 3 short foraging trips at the Crozet shelf break performed by whitechinned petrels rearing chicks

distance reached during individual foraging trips showed a bimodal distribution with no intermediate range between 115 and $826 \mathrm{~km}$ (Fig. 1a). Birds either foraged at short distances from the colony, over the Crozet shelf and shelf break ( $n=5$ trips) (Fig. 2) during trips of short duration (0.3 to $2.4 \mathrm{~d}$, Table 1$)$, or at long distances from the Crozet Islands during longer trips $(2.8$ to $12.9 \mathrm{~d})$ covering an extended area of the southwestern Indian Ocean $(n=9)$ (Figs. $3 \& 4$ ). Consequently, we defined 2 kinds of foraging trips, short trips (ST) and long trips (LT), which lasted less and more than $2.5 \mathrm{~d}$, respectively. The mean maximum foraging range was 62 and $1868 \mathrm{~km}$ for ST and LT, respectively, with the maximum distance from the colony reached during LT being $2421 \mathrm{~km}$ (Table 1). Tracked birds covered a mean total distance of $5481 \mathrm{~km}$ during LT and only $196 \mathrm{~km}$ during ST (Table 1 ).

During ST, white-chinned petrels foraged in a specific area located on the Crozet shelf break, southwest of Ile de la Possession (Fig. 2). During LT, birds ranged from subtropical waters in the nor th to Antarctic waters in the south. Two LT occurred to the north of the Crozet Islands (Fig. 3); 1 trip followed a small looping course to the northwest (C-71-1; see Table 1 for explanation of track numbers), and the other reached subtropical waters at $31^{\circ} \mathrm{S}$ during a looping course to the northeast of the archipelago (C-74-1) The 7 other LT occurred in Antarctic waters. Five of them exhibited a similar pattern, with the birds commuting to a specific site located within a narrow latitudinal zone, between 61 and $62^{\circ} \mathrm{S}$ (Figs. 3 \& 4). Three different foraging sites were thus identified. Two sites each were used by 2 birds $(C-72-1$ and $C-69-1$, and $C-73-1$ and $C-69-3$, respectively), and the last site by 1 petrel (C-71-2) (Figs. $3 \& 4$ ). The last 2 LT were performed by the same bird (C-70) which foraged in Antarctic waters, south of the other tracks 


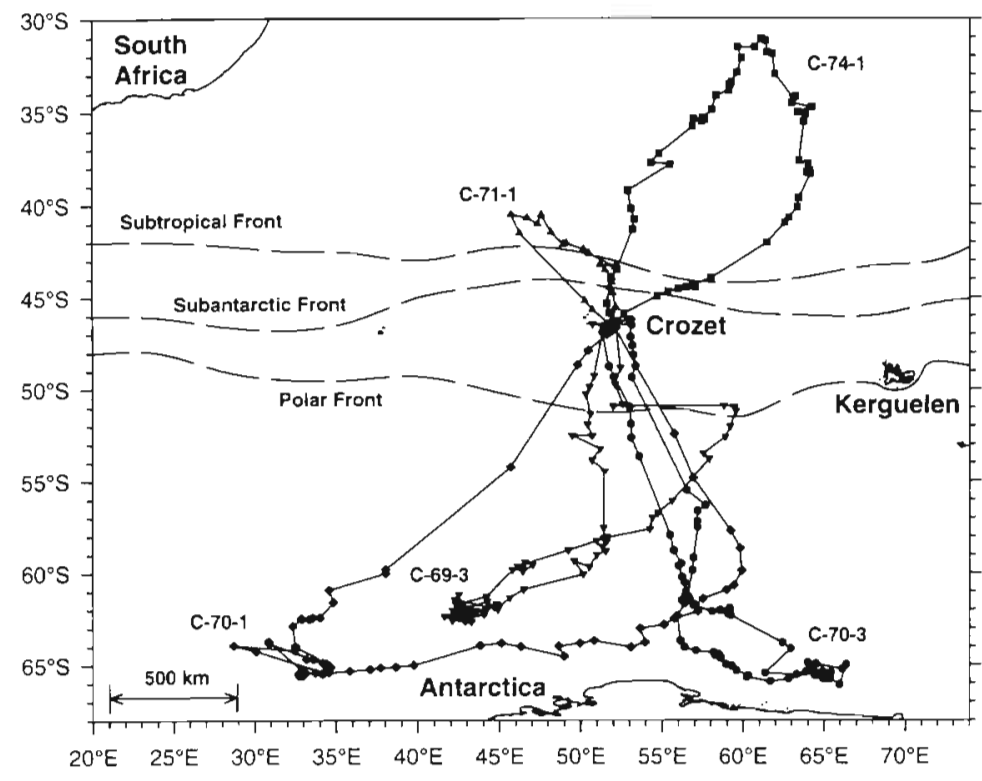

Fig. 3. Procellaria aequinoctialis. Detailed tracks of 5 long foraging trips from subtropical to Antarctic waters performed by white-chinned petrels rearing chicks at the Crozet Islands, southwestern Indian Ocean. Position of fronts follows Park et al. (1993)

along the Antarctic continent and did not concentrate its foraging effort in a particular area (Fig. 3).

The distribution of time spent foraging at different water depths indicated that, during ST, birds were confined either on the Crozet Islands shelf (water depth $<200 \mathrm{~m})$, or over mid-slope waters $(1000$ to $2000 \mathrm{~m}$ depth), thus contrasting with the predominance of time spent foraging in oceanic waters over great depths (>4000 m) during LT (Fig. 5). The marine zones exploited by white-chinned petrels during LT exhibited a wide range of sea-surface temperatures,

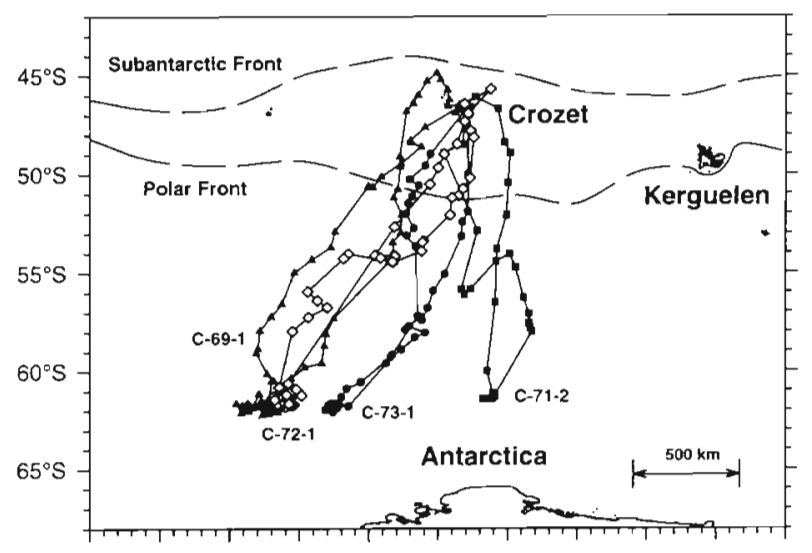

$25^{\circ} \mathrm{E} \quad 30^{\circ} \mathrm{E} \quad 35^{\circ} \mathrm{E} \quad 40^{\circ} \mathrm{E} \quad 45^{\circ} \mathrm{E} \quad 50^{\circ} \mathrm{E} \quad 55^{\circ} \mathrm{E} \quad 60^{\circ} \mathrm{E} \quad 65^{\circ} \mathrm{E} \quad 70^{\circ} \mathrm{E} \quad 75^{\circ} \mathrm{E}$

Fig. 4. Procellaria aequinoctialis. Detailed tracks of 4 long foraging trips over Antarctic waters performed by whitechinned petrels rearing chicks at the Crozet Islands, southwestern Indian Ocean from -0.5 to $+24^{\circ} \mathrm{C}$, with a prominent peak at $+2{ }^{\circ} \mathrm{C}$ (Fig, 6). Overall, the birds spent $62.5 \%$ of their time at sea during LT foraging in Antarctic waters, and 2.4, 23.0 and $12.1 \%$ foraging over the Polar Front, in Polar Frontal Zone waters, and north of the sub-Antarctic Front, respectively.

\section{Food provisioning}

Feeding frequency and duration of trips

The proportion of adult birds visiting the chick varied significantly from 1 day to the next over the $3 \mathrm{wk}$ study period $\left(\chi^{2}{ }_{19}=\right.$ $56.58, \mathrm{p}<0.001$ ), the mean value being $0.53 \pm 0.18$ visits $\mathrm{d}^{-1}$ (range: 0.14 to 0.80 ). Feeding frequency $\left(0.51 \pm 0.15\right.$ feedings $\mathrm{d}^{-1}$; range: 0.23 to 0.76 ) was slightly lower than visit frequency because no increase in chick body mass was observed after a few visits by adult petrels. The time elapsed between 2 successive adult visits in the burrow was $2.1 \pm 0.8 d_{1}$ suggesting a mean trip duration of individual adult birds equal to $4.2 \mathrm{~d}$.

Individual adult petrels were identified in 160 out of 215 recorded visits to the chick, with most of the 55 missing identifications resulting from visits of a dura-

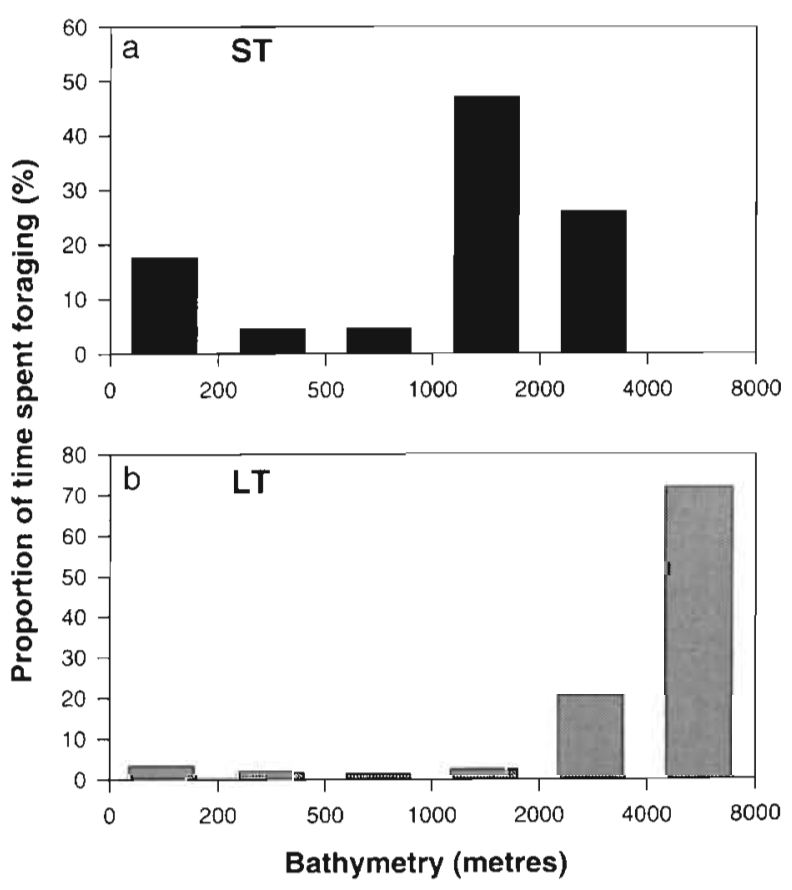

Fig. 5. Procellaria aequinoctialis. Frequency distribution of bird-hours spent in zones of different water-depths during (a) short trips (ST), and (b) long trips (LT) 


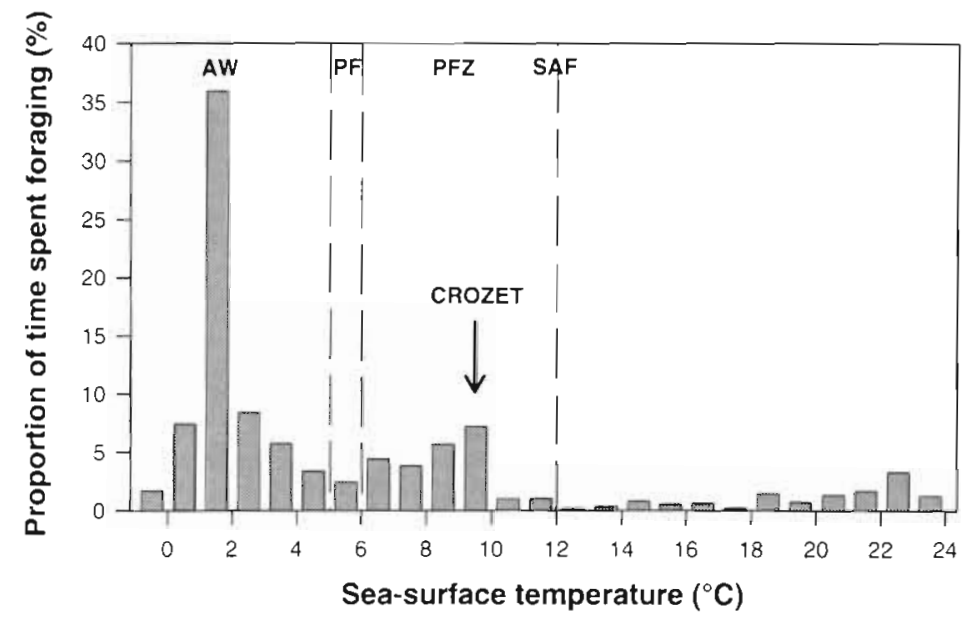

Fig. 6. Procellaria aequinoctialis. Distribution of bird-hours spent in zones of different sea-surface temperatures during long trips. AW: Antarctic waters, PF: Polar Front, PFZ: Polar Frontal Zone, SAF: sub-Antarctic Front

tion too short $(<30 \mathrm{~min})$ to be detected. Ninety-six individual foraging trip durations were determined, ranging from $1.5 \mathrm{~h}$ to $11 \mathrm{~d}$ (Fig. $1 \mathrm{~b}$ ). The duration of ST and LT averaged $0.9 \pm 0.6$ and $6.2 \pm 2.5 \mathrm{~d}$, respectively, with the number of ST predominating over that of LT (69 vs $31 \% ; n=96$ visits of known duration). When birds

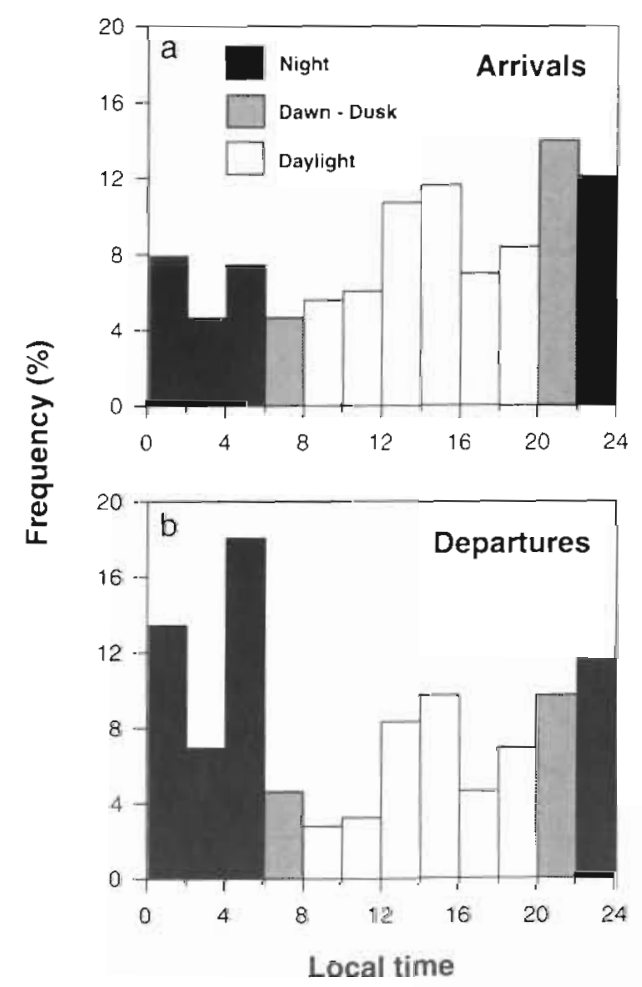

Fig. 7. Procellaria aequnoctialis. Frequency distribution of (a) arrival and (b) departure time of foraging trips $(\mathrm{n}=215$ ) of white-chinned petrels rearing chicks. During the study period, mean sunrise occurred at $06: 26 \mathrm{~h}$ and mean sunset at 21:07 h local time (GMT +5) returned from a LT $(\mathrm{n}=22)$, most of them ( $\mathrm{n}=$ $20,91 \%$ ) started a succession of several (1 to 6) ST (1 bird performed 11 ST before starting a LT), with only 2 of them (9\%) starting another LT. The succession of foraging trips was not random; on average 1 LT was followed by $2.2 \mathrm{ST}$. Hence, for 14 birds for which the succession of trips was known throughout the entire study period, they spent on average $64 \pm 23 \%$ of their foraging time on LT.

No significant differences between females and males were found when comparing foraging time spent on LT $(t=0.08, p=0.92)$, foraging trip duration ( $t=0.64, p=0.51)$, and their frequency distribution of trip duration, either ST or LT $\left(\chi_{1}^{2}=0.25, \mathrm{p}=0.61\right)$. Neither females nor males tended to make more 1,2 or $3 \mathrm{~d}$ trips $\left(\chi_{2}^{2}=2.79, \mathrm{p}=0.2\right)$.

To test if the transmitters had an effect on foraging behaviour, we compared the time spent at sea between equipped and unequipped white-chinned petrels (see Table 1 and results above, respectively). The differences between the 2 groups were not significant for ST ( $t=0.81, p=0.42)$ but significant for LT $(t=2.04$, $p=0.05)$. The 6 adult petrels equipped with satellite transmitters spent significantly more time on LT than the unequipped birds $(86 \pm 10 \%, t=2.91, p=0.009)$, mainly because they always started a LT after being equipped

\section{Hours of arrival and departure}

We recorded 215 arrival and departure times of white-chinned petrels rearing chicks. During the study period $58 \%$ of arrivals and $42 \%$ of departures occurred during daytime, which lasted on average $14.5 \mathrm{~h}$ (from sunrise to sunset). The number of arrivals tended to increase throughout the day, with a maximum reached at dusk, while departures peaked at the end of nighttime (Fig. 7).

\section{Meal size}

The mean mass of meals delivered to the chick by a single parent was $144 \pm 88 \mathrm{~g}$ (range: 3 to $410 \mathrm{~g}, \mathrm{n}=$ 169). There was no significant relationship between the duration of foraging trips and meal size when meal masses from all trip durations were pooled ( $\mathrm{r}=0.195$, $\mathrm{n}=68, \mathrm{p}>0.1$ ). However, meals delivered after LT were significantly heavier than those delivered after ST $(205 \pm 102$ vs $133 \pm 76 \mathrm{~g}$, respectively, $t=2.7, \mathrm{p}=$ $0.01)$. There was no sex difference in meal size for 
all trips combined $(t=0.06, p=0.9)$, nor for either ST $(t=0.11, \mathrm{p}=0.9)$ or LT $(t=0.66, \mathrm{p}=0.5)$.

The time elapsed since the previous meal had no significant influence on the mass of the meal delivered $(\mathrm{r}=0.283, \mathrm{n}=153, \mathrm{p}>0.1)$. Meal mass was significantly larger for chicks in poor body condition $(r=0.316, n=$ $170, p>0.001$ ). Chick body condition had no influence on the decision of adults to start a ST or a LT $\left(\chi^{2}{ }_{1}=1.59\right.$, $p=0.9)$. There was no significant relationship between chick body condition and foraging trip duration ( $\mathrm{r}=$ $0.200, \mathrm{n}=68, \mathrm{p}=0.09$, and $\mathrm{r}=0.387, \mathrm{n}=22, \mathrm{p}=0.07$, for ST and LT, respectively).

The mean chick provisioning rate calculated over the 3 wk study period averaged $79 \pm 29 \mathrm{~g} \mathrm{~d}^{-1}$

\section{Diet}

The stomach contents of chicks were composed of a liquid fraction made of oil $(24 \pm 25 \mathrm{ml}, \mathrm{n}=23)$ and water, and a solid fraction $(179 \pm 73 \mathrm{~g})$ made of more or less digested prey items $(177 \pm 73 \mathrm{~g})$ and of accumulated prey items $(2 \pm 2 \mathrm{~g})$ such as squid beaks. Overall, the diet was dominated by fish, which alone accounted for $79.3 \%$ of the diet by mass. Other significant food sources were squid $(11.7 \%)$ and crustaceans $(9.0 \%)$, while gelatinous zooplankton was negligible $(<0.1 \%)$. ST samples contained more fish ( 91.5 vs $67.4 \%$ ), but less squid ( 8.0 vs $15.3 \%$ ) and crustaceans $(0.5 \%$ vs $17.3 \%)$ than the LT samples. The difference by mass between ST and LT samples was significant only for crustaceans (Kruskal-Wallis, $U=31, p<0.05)$.

A total of 1148 prey items was identified, including 690 items from ST samples and 458 from LT samples. A total of 27 different prey taxa were identified (Table 2). Crustaceans dominated the diet by number, accounting for 94.9 and $91.5 \%$ of the total number of prey in ST and LT samples, respectively. Antarctic krill Euphausia superba was the most abundant crustacean prey in LT samples compared to ST (86.5 vs $26.5 \%$ ), while the hyperiid amphipod Themisto gaudichaudii was the major item in ST samples (66.2 vs $2.4 \%$ ). Among fish prey, the paralepidid Magnisudis prionosa, together with different species of myctophids, accounted for most of the identified items (21 out of 38 individuals). Remaining common fish items were mainly found in ST samples. They consisted of pieces of broken bones and skin of large individuals of Patagonian toothfish Dissostichus eleginoides, and of the clupeid Sardinops sp., which is not known to occur in the area. This is also the case for the ommastrephid squid Illex argentinus that was found in some ST samples (Table 2). The lack of buccal masses precluded the identification of most of the fresh squid remains. How- ever, the only common squid species identified from accumulated beaks was the histioteuthid Histioteuthis eltaninae.

Five LT food samples were collected from chicks just fed by satellite-tracked birds. Of these, 3 contained digested remains of Antarctic krill ( $\mathrm{n}=17$ to 29 individuals) associated either with Magnisudis prionosa (C-72-1, Fig. 4), or undetermined squids (C-71-2 and C-73-1). One sample (C-70-1, Fig. 3) consisted of fish flesh and broken bones of Patagonian toothfish together with 1 Sardinops sp. and 1 unidentified fish, while the last food sample (C-74-1) only contained crustaceans, including 1 large unidentified decapod and 4 Themisto gaudichaudii.

\section{DISCUSSION}

\section{Short trips and long trips in foraging seabirds during chick rearing}

The use of a dual strategy whereby adults alternate ST with LT during the chick-rearing period has recently been detailed for several other species of procellariiforms, including albatrosses (Weimerskirch 1998a, Waugh et al. 1999), petrels and prions (Chaurand \& Weimerskirch 1994, Weimerskirch et al. 1994, 1999a), and shearwaters (Granadeiro et al. 1998, Weimerskirch 1998b, Weimerskirch \& Cherel 1998). This study shows that white-chinned petrels from the Crozet Islands also use such a dual strategy and is the first study to report this behaviour for a Procellaria species. In this foraging strategy adult body condition plays a central role in the decision to perform either a LT or a ST, because adults build up energy reserves during LT. They subsequently use the stored energy to forage, in order to increase the chick-provisioning rate during 1 or several successive ST (Weimerskirch 1998b, Weimerskirch et al. 1999a). Although we have no information on the changes in adult mass of whitechinned petrels, it is very likely that, similar to other species studied so far, the body condition of adults is a key factor in determining foraging decisions on whether to do a ST or a LT. Our study demonstrates that the condition of the chick does not influence the decision to start a LT or a ST

In previous studies, dietary information suggested that adult procellariiforms forage in waters close to the colony during ST and further offshore during LT (Chaurand \& Weimerskirch 1994, Weimerskirch \& Cherel 1998, Weimerskirch et al. 1999a) and this has been confirmed by satellite tracking studies (Weimerskirch et al. 1997 a, Waugh et al. 1999). A similar pattern between temporal and spatial components of foraging trips in satellite-tracked white-chinned petrels 
Table 2. Procellaria aequinoctialis. Prey species in stomach contents of chicks after short (ST; $\mathrm{n}=10$ ) and long (LT; $\mathrm{n}=13$ ) foraging trips of adult white-chinned petrels at the Crozet Islands

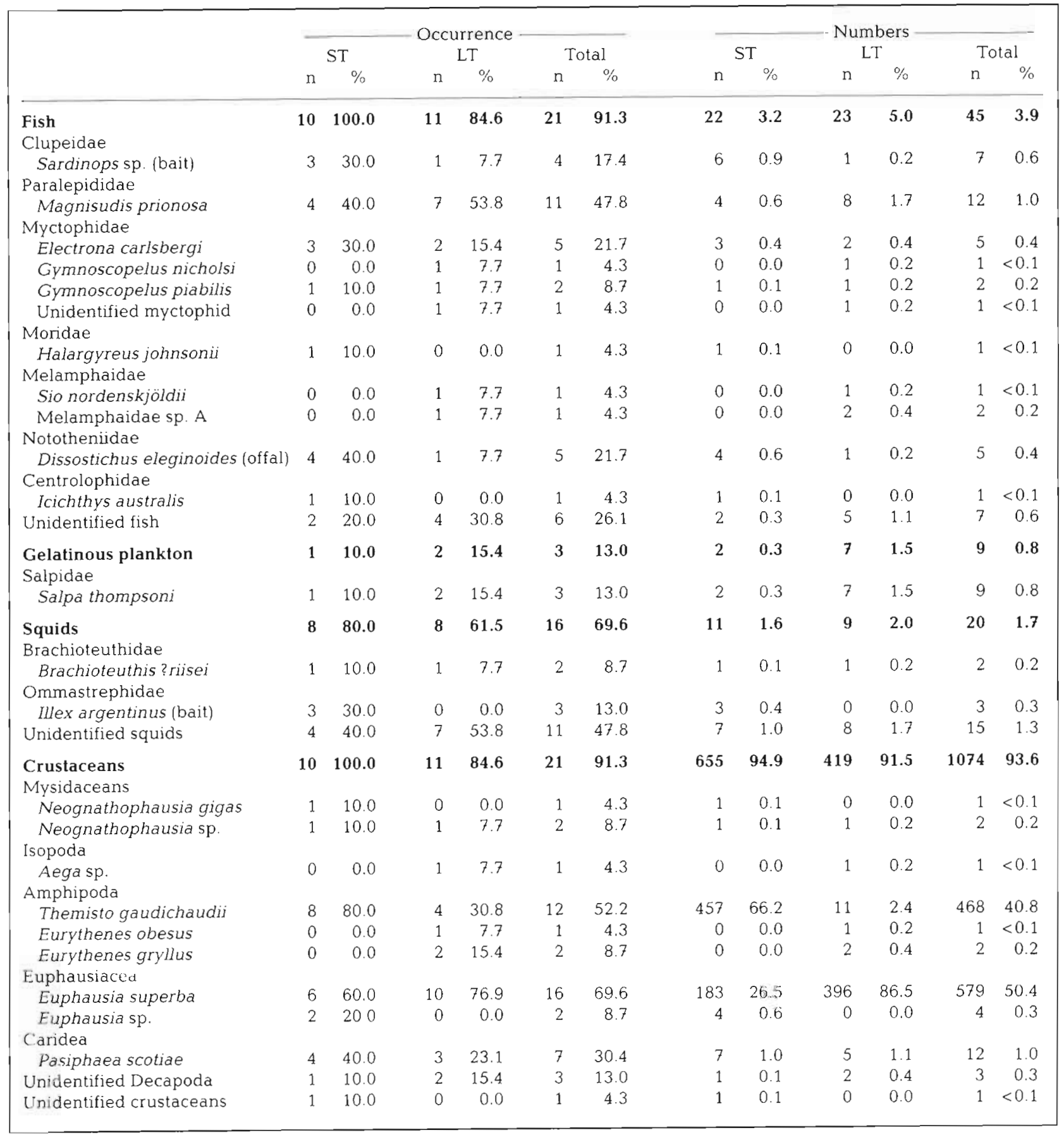

also confirmed iris pattern. White-chinned petrels foraged in neritic and slope waters nearby the colony during ST, and in oceañic waters from the subtropics to Antarctica during $\mathrm{LT}$.

An unexpected finding of the study was that, unlike other burrowing petrels at similar latitudes (Warham 1990), white-chinned petrels returned and left the bur- row during the day as well as at night (Fig. 7). Diurnal visits may be possible in this species because of its large size, which allows it to avoid predation by the brown skua Catharacta antarctica lönnbergi during the day. Similar results have been obtained for the same species at South Georgia (Berrow \& Croxall 1999). 


\section{Foraging over the Crozet shelf break and the use of fisheries}

During ST, satellite-tracked white-chinned petrels did not forage randomly in Crozet waters, but tended to commute to a specific area located over the southwestern edge of the shelf surrounding Possession Island. There, most of the time spent by birds occurred over mid-slope waters (1000 to $2000 \mathrm{~m}$ depth). Interestingly, wandering albatrosses from Possession Island also foraged over the Crozet shelf break during ST, but they fed mainly in another area, at the southeastern edge of the peri-insular shelf (Weimerskirch et al. 1993, 1997a). Observations at sea also indicated that white-chinned petrels are abundant in neritic and slope waters around the Crozet Islands in JanuaryFebruary (Stahl et al. in press). These studies emphasise the importance of the productive outer shelf and slope waters for the nutrition of seabirds, as also recently shown for black-browed albatrosses Diomedea melanophrys at Kerguelen Island and in the South Atlantic (Weimerskirch et al. 1997b, Prince et al. 1998), Buller's albatross D. bulleri in New Zealand (Sagar \& Weimerskirch 1996), and shy albatrosses $D$. cauta in southern Australia (Brothers et al. 1998).

Collecting food samples from chicks, and not from the adults, complicated the identification of prey resulting from either a ST or a LT through the mixing of items recently delivered by adults with those accumulated from previous meals. This explains, for example, the presence in ST samples of a significant number of Antarctic krill, which obviously do not occur in the area and could not be caught within $2 \mathrm{~d}$ (see below). The most numerous prey (which, owing to its small size, accounted for a small biomass) was the amphipod Themisto gaudichaudii. This pelagic schooling species is abundant between the Subtropical and Polar Fronts (Pakhomov \& McQuaid 1996); it was previously found to be a common prey of white-chinned petrels at the Crozet and Marion Islands (Cooper et al. 1992, Ridoux 1994) and is a key species for the nutrition of the seabird community breeding there (Ridoux 1989).

Chicks were fed mainly with various fish species after ST. Surprisingly, a significant proportion of prey items identified in ST samples belonged to species that do not occur naturally in Crozet waters. The fish Sardinops sp. (probably $S$. ocellatus that is heavily fished in South African waters; Whitehead 1985) and the squid Illex argentinus, which only occurs off eastern South America (Roper et al. 1998), were each found in $30 \%$ of the ST samples. Since these species are known to be used as bait by longliners targetting the Patagonian toothfish Dissostichus eleginoides (G. Duhamel pers. comm.), the most likely explanation of their presence in the chick food is that adult white- chinned petrels foraged behind fishing vessels during some ST. Remains of Patagonian toothfish were recorded in $40 \%$ of ST samples. They consisted of pieces of broken bones, skin and flesh from individual fish, by far too large to be swallowed whole by seabirds and which are moreover known to live at the bottom in slope waters (Duhamel 1992). Again, the most likely explanation is that birds fed on fishery waste, probably on offal (coarsely chopped fish heads, tails and guts) piped overboard on some longliners (Cherel et al. 1996). Taken together, 'artificial' prey were present in $70 \%$ of ST food samples, suggesting considerable interaction between white-chinned petrels and fishing vessels around the Crozet Islands in February 1997. No fishery waste was found previously in the diet of whitechinned petrels in the southwestern Indian Ocean (Cooper et al. 1992, Ridoux 1994), suggesting that interaction with fisheries is a recent phenomenon. Longlining only started around Crozet in the mid-1990s.

White-chinned petrels are well-known ship-following seabirds on both their breeding and wintering grounds (Ryan \& Moloney 1988, Cherel et al. 1996), thus being at risk of being killed by fishing vessels (when caught by baited hooks and drowned) almost everywhere in the Southern Ocean, from the tropics to Antarctica (Weimerskirch et al. 1999a). Illegal longline fishing for Patagonian toothfish occurred around the Crozet Islands during the study period, with at least 45 vessels belonging to 8 countries estimated during 1997 (G. Duhamel pers. comm., based on French Navy, island residents' and controllers' observations). Our study thus indicates a high level of interaction between the illegal fishery and seabirds, including whitechinned petrels, around the Crozet Islands in February 1997. This is of major concern for seabird conservation, since the white-chinned petrel has frequently been recorded as the main species killed by longliners (Vaske 1991, Ashford et al. 1995, Cherel et al. 1996, Barnes et al. 1997). The total number of white-chinned petrels killed per year in the Indian Ocean by legal fisheries can reach 15000 individuals, and it was estimated to total up to 45000 birds when illegal fisheries are included in the calculation (CSIRO 1993, Barnes et al. 1997, CCAMLR 1997).

\section{Foraging in Antarctic and subtropical oceanic waters}

During LT, white-chinned petrels rearing chicks foraged from the subtropics to Antarctica, in an extended area comparable only to that of the largest flying seabird, the wandering albatross (Weimerskirch et al. 1993, 1997a). These data are in agreement with results during incubation, which show that earlier in the breeding cycle, white-chinned petrels from the Crozet 
Islands forage from the Benguela current off South Africa to the edge of the pack-ice near the Antarctic continent (Catard \& Weimerskirch 1999, Weimerskirch et al. 1999a). No significant difference was found when comparing the mean duration, total distance covered and maximum range of LT with those of incubation trips (Catard \& Weimerskirch 1999, present study). A noticeable difference between the 2 periods was, however, that birds foraged more in subtropical and subAntarctic waters during incubation (December 1996), and more in Antarctic waters during chick rearing (February 1997), with adult white-chinned petrels shifting to more southern waters as the austral summer advanced. This pattern is consistent with previous atsea surveys of seabirds showing that white-chinned petrel densities in Antarctic waters increase from spring (November-December) to summer (JanuaryMarch) (Woehler et al. 1990. Stahl et al. in press). At this time, white-chinned petrels and Antarctic prions Pachyptila desolata, another bird performing ST and LT during chick rearing (Weimerkirch et al. 1999b), are numerous in the Antarctic Indian Ocean, foraging in open waters and avoiding the pack-ice zone (Veit \& Hunt 1991).

The single bird that performed 2 trips to $66^{\circ} \mathrm{S}$ along the Antarctic shelf $(\mathrm{C}-70-1$ and $\mathrm{C}-70-3$; Fig. 3 ), probably followed the limit of the pack-ice. The 4 other birds which flew to Antarctic waters concentrated their foraging effort farther north, between 61 and $62^{\circ} \mathrm{S}$ (Figs. 3 $\& 4)$. These latitudes fit well with the maximum extent of the sea ice that reached 60 to $61^{\circ} \mathrm{S}$ in September 1996. During spring and summer, as the pack-ice retreats, the productive Antarctic waters are invaded by predators that feed on the abundant marine resources, including Antarctic krill (Ainley \& DeMaster 1990). Major concentrations of krill occur in the southwest Indian Ocean (Miller \& Hampton 1989). In the Prydz Bay region, the northern limit for Antarctic krill was $59^{\circ} \mathrm{S}$, but few individuals are collected north of $62^{\circ} \mathrm{S}$, the highest densities being recorded south of $66^{\circ} \mathrm{S}$ (Hosie et al. 1988, Miquel 1991). There, krill populations occur in water temperatures between -1.5 and $+2.0^{\circ} \mathrm{C}$ (Miquel 1991)

During LT, adult white-chinned petrels spent a larger amount of time foraging over oceanic waters where the sea-surface temperature is about $+2^{\circ} \mathrm{C}$. Following LT, chicks were mainly fed fish, though crustaceans, mainly Antarctic krill, accounted for a significant part of the diet. Taken together the data on krill distribution and bird foraging distribution suggest that during LT white-chinned petrels foraged in the northern part of the zone where krill occur. They possibiy fed on the first large swarms they encountered, spent some time foraging in the area of high krill concentration, and then went back to the colony in a straight line. The main fish prey caught during LT, the paralepidid Magnisudis prionosa, has a broader geographic distribution than krill, occurring from $20^{\circ} \mathrm{S}$ to Antarctica, while the species of myctophids taken occur mainly north of the Polar Front (Gon \& Heemstra 1990), which lies at $50^{\circ} \mathrm{S}$, south of the Crozet Islands (Park et al. 1993). White-chinned petrels, therefore, forage on their way back to the colony to feed their chicks, both with digested remains of prey swallowed in Antarctica (krill) and more fresh items (fish) collected, in part at least, in the Polar Frontal Zone, and even in the Crozet Islands slope waters. Indeed, 1 LT food sample collected after the chick was fed by a satellite-tracked bird (C-70-1) contained fresh fishery wastes, i.e. bait (Sardinops sp.) and offal (Dissostichus eleginoides) that were scavenged behind longliners on the way back from Antarctica.

Food samples collected at the Crozet Islands in 1983 contained less fish (55\% by mass) and more squid $(25 \%)$ and crustaceans $(16 \%)$ than in the present study (Ridoux 1994), probably reflecting interannual variability in prey availability. However, Antarctic krill again predominated among crustaceans, suggesting that foraging in distant southern Antarctic waters is a constant feature of white-chinned petrels rearing chicks at the Crozet Islands. At South Georgia, Antarctic krill is the single most important prey item ( $47 \%$ by mass j of the white-chinned petrel, which is the third most important avian consumer of krill in the area (Croxall et al. 1995). The high availability of Euphausia superba around South Georgia (which is located south of the Polar Front) probably explains, in part, why so many white-chinned petrels breed there compared to the Crozet Islands (2000000 vs 30000 pairs, respectively; Marchant \& Higgins 1990). The proximity of the main feeding grounds around South Georgia could also explain why at this latter site, compared to Crozet, birds perform shorter trips to reach krill swarms when they rear chicks (Berrow et al. in press). For this reason a dual strategy may be less apparent or may not occur for the species at South Georgia. Similarly, Cory's shearwaters and black-browed albatrosses use a dual strategy at some sites but not at others (Granadeiro et al. 1998, Waugh et al. 1999). In fact, the existence of a dual strategy is probably related to the distance between the breeding colonies and foraging grounds, and it is thus not surprising that within the same species differences between sites or between season in the same site occur (Weimerskirch 1999).

Surprisingly, birds from Marion Island which also feed on fish ( $57 \%$ by mass). squid $(17 \%)$ and crustacears (24\%), do not catch Antarctic krill, but do catch the sub-Antarctic krill Euphausia vallentini, which commonly occurs in the vicinity of the Marion and Crozet Islands (Cooper et al. 1992), Clearly, fur- 
ther information is needed to investigate such important dietary, and probably foraging, differences between birds breeding in these closely associated archipelagos.

No significant differences between sexes were found in foraging trip duration or in meal size, suggesting identical parental investment between males and females during the chick-rearing period. However, all 4 searching flights, where birds flew continuously in looping courses, recorded in subtropical waters and along the Antarctic pack-ice were performed by females. All but 1 commuting flight, where birds flew rapidly to specific marine areas located at 61 to $62^{\circ} \mathrm{S}$ in Antarctic waters, were performed by males. This suggests different foraging strategies between males and females, as previously reported for the grey petrel Procellaria cinerea (Bartle 1990) and the wandering albatross (Weimerskirch et al. 1997a). Sex-biased bycatch of white-chinned petrels in longliners (Ryan \& BoixHinzen 1999) also suggests differences in the foraging ecology of males and females in this species. However, further work is needed to increase the number of satellite-tracked birds and hence to investigate spatial segregation between male and female white-chinned petrels.

There has been increasing evidence over recent years that many procellariiforms breeding north of the Polar Front forage in Antarctic waters, hence at several hundred, if not thousands, of kilometres away from their colonies. Satellite tracking and/or dietary analysis has proved that at least some of the birds of unknown status commonly encountered in Antarctic waters were individuals engaged in breeding activities such as incubation and chick-rearing, and not immatures or failed breeders. At Crozet and Kerguelen, bird species foraging south of the Polar Front while breeding include the wandering, grey-headed Diomedea chrysostoma and light-mantled sooty Phoebetria palpebrata albatrosses, Antarctic and thin-billed $P$. belcheri prions, and the blue petrel Halobaena caerulea (Weimerskirch et al. 1993, 1999b, Chaurand \& Weimerskirch 1994, Ridoux 1994, author's unpubl. data). To date the most spectacular example of this strategy is the finding that short-tailed shearwaters Puffinus tenuirostris in southern Australia $\left(43^{\circ} \mathrm{S}\right)$ may forage near Antarctica $\left(63^{\circ} \mathrm{S}\right)$, more than $2000 \mathrm{~km}$ away from their breeding colony, during the chick-rearing period (Klomp \& Schultz 1998, Nicholls et al. 1998). Despite this extreme foraging range this shearwater is still able to provision its chick at a sufficient rate by using a 2fold strategy, foraging during ST in neritic waters around the breeding grounds in Australia (Weimerskirch \& Cherel 1998). All these species are known to use a dual strategy similar to that found in the present study in white-chinned petrels, enabling adult birds to alternate use of waters close to the colonies and Antarctic waters, where most of them probably feed on the most abundant resource, the Antarctic krill. Observations at sea in January-February suggest that other procellariiform seabirds, such as white-headed Pterodroma lessoni and the mottled $P$. inexpectata petrels (Veit \& Hunt 1991), also perform LT to Antarctica, and hence, that the dual strategy of ST and LT during chick rearing is widespread among birds from the Southern Ocean.

Acknowledgements. The authors thank D. Aures, P. Lys and members of the 33rd and 34th mission on Possession Island for their field assistance, $C$. Trouvé for her help in food analysis, and C. Troup for improving the English. This study was supported financially and logistically by the Institut Français pour la Recherche et la Technologie Polaires (programme no. 109) and the Terres Australes et Antarctiques Françaises. We thank Paul Sagar and 3 anonymous referees for helpful and constructive comments on an earlier version of the manuscript.

\section{LITERATURE CITED}

Abrams RW (1985) Energy and food requirements of pelagic aerial seabirds in different regions of the African sector of the Southern Ocean. In: Siegfried WR, Condy PR, Laws RM (eds) Antarctic nutrient cycles and food webs. Springer Verlag, Berlin, p 466-472

Ainley DG, DeMaster DP (1990) The upper trophic levels in polar marine ecosystems. In: Smith WO (ed) Polar oceanography, Part B: chemistry, biology and geology. Academic Press, San Diego, p 599-630

Ashford JR, Croxall JP, Rubilar PS, Moreno CA (1995) Seabird interactions with longlining operations for Dissostichus eleginoides around South Georgia, April to May 1994. CCAMLR Sci 2:111-121

Ashmole NP (1971) Seabird ecology and the marine environment. In: Farner DS, King JR, Parkes KC (eds) Avian biology, Vol 1. Academic Press, New York, p 223-286

Baker AdeC, Boden BP, Brinton E (1990) A practical guide to the euphausiids of the world. Natural History Museum Publications, London

Barnard JL (1961) Gammaridean Amphipoda from depths of 400 to 6000 meters. Galathea Rep 5:23-128

Barnes KN, Ryan PG, Boix-Hinzen C (1997) The impact of the hake Merluccius spp. longline fishery off South Africa on Procellariiform seabirds. Bial Conserv 82:227-234

Bartle JA (1990) Sexual segregation of foraging zones in procellariiform birds: implications of accidental capture on commercial fishery longlines of grey petrels (Procellaria cinerea). Notornis 37:146-150

Berrow SD, Croxall JP (1999) The diet of white-chinned petrels Procellaria aequinoctialis Linnaeus 1758, in years of contrasting prey availability at South Georgia. Antarct Sci 11:283-292

Berrow SD, Woods AG, Prince PA (in press) Foraging range and location of white-chinned petrels breeding in the South Atlantic. J Avian Biol

Bierman WH, Voous KH (1950) Birds observed and collected during the whaling expeditions of the 'Willem Barend $z$ ' in the Antarctic, 1946-1947 and 1947-1948. Ardea 37:1-123

Brothers N, Gales R, Hedd A, Robertson G (1998) Foraging 
movements of the shy albatross Diomedea cauta breeding in Australia; implications for interactions with longline fisheries. Ibis 140:446-457

Brown RGB (1980) Seabirds as marine animals. In: Burger J, Olla BL, Winn ME (eds) Behavior of marine animals, Vol 4. Plenum Press, New York, p 1-39

Catard A, Weimerskirch $H$ (1999) Satellite tracking of whitechinned petrels and comparison with other Procellariiformes. In: Adams N, Slotow R (eds) Proc 22 Int Ornithol Congr University of Natal, Durban, p 3008-3023

CCAMLR (Convention for the Conservation of Antarctic Marine Living Resources) (1997) Report of the fifteenth meeting of the commission. CCAMLR, Hobart. CCAMLR Annex 5:85-114

Chaurand T, Weimerskirch H (1994) The regular alternation of short and long foraging trips in the blue petrel Halobaena caerulea: a previously undescribed strategy of food provisioning in a pelagic seabird. J Anim Ecol 63:275-282

Cherel Y, Weimerskirch H (1995) Seabirds as indicators of marine resources: black-browed albatrosses feeding on ommastrephid squids in Kerguelen waters. Mar Ecol Prog Ser 129:295-300

Cherel $Y$, Weimerskirch $H$, Duhamel $G$ (1996) Interactions between longline vessels and seabirds in Kerguelen waters and a method to reduce seabird mortality. Biol Conserv 75:63-70

Clarke MR (1986) A handbook for the identification of cephalopod beaks. Clarendon Press, Oxford

Cooper J, Fourie A, Klages NTW (1992) The diet of the whitechinned petrel Procellaria aequinoctialis at subAntarctic Marion Island. Mar Ornithol 20:17-24

Croxall JP, Prince PA (1980) Food, feeding ecology and ecological segregation of seabirds at South Georgia. Biol J Linn Soc 14:103-131

Croxall JP, Hall AJ, Hill HJ, North AW, Rodhouse PG (1995) The food and feeding ecology of the white-chinned petrel Procellaria aequinoctialis at South Georgia. J Zool Lond 237:133-150

Croxall JP, Reid K, Prince PA (1999) Diet, provisioning and productivity responses of marine predators to difference in availability of Antarctic krill. Mar Ecol Prog Ser 177: $115-131$

CSIRO (1993) Report of the 12th SBT trilateral scientific meeting, Vol 1. CSIRO Marine laboratories, Hobart

Duhamel G (1992) Biologie et exploitation de Dissostichus eleginoides autour des lles Kerguelen (Division 58.5.1). CCAMLR, WG-FSA-91/9

Fancy SG, Pank, LF Douglas DC, Curby CH, Garner GW, Amstrup SC, Regelin WL (1988) Satellite telemetry: a new tool for wildlife research and management. US Fish Wildl Serv Publ 172:1-54

GEBCO (1997) 1997 Edition of the IOC/IHO General batyhmetric chart of the oceans. British Oceanographic Centre, Merseyside

Gon O, Heemstra PC (1990) Fishes of the Southern Ocean JLB Smith Institute of Ichthyology, Grahamstown

Granadeiro JP, Nunes M, Silva MC, Furness RW (1998) Flexible foraging strategy of Cory's shearwater, Calonectris diomedea, during the chick-rearing period. Anim Behav 56:1169-11.76

Guinet C, Koudil M, Bost CA, Durbec JP, Georges JY, Mouchot MC, Jouventin P (1997) Foraging behaviour of satellite-tracked king penguins in relation to sea-surface temperatures obtained by satellite telemetry at the Crozet Archipelago, a study during three austral summers. Mar Ecol Prog Ser 150:11-20

Hall AJ (1987) The breeding biology of the white-chinned petrel Procellaria aequinoctialis at South Georgia. J Zool Lond 212:605-617

Hosie GW, Ikeda T, Stolp M (1988) Distribution, abundance and population structure of the Antarctic krill (Euphausia superba Dana) in the Prydz Bay region, Antarctica. Polar Biol 8:213-224

Huin N (1994) Diving depths of white-chinned petrels. Condor 96:1111-1113

Hull CL, Hindell MA, Mickael K (1997) Foraging zones of royal penguins during the breeding season, and their associations with oceanographic features. Mar Ecol Prog Ser 153:217-228

Hunt GL (1991) Marine ecology of seabirds un polar oceans. Am Zool 31:131-142

Hunt GL, Schneider DC (1987) Scale-dependent processes in the physical and biological environment of marine birds. In: Croxall JP (ed) Seabirds: feeding ecology and role in marine ecosystems. Cambridge University Press, Cambridge, p 7-42

Jackson S (1988) Diets of the white-chinned petrel and sooty shearwater in the Southern Benguela region, South Africa. Condor 90:20-28

Jouventin P, Weimerskirch H (1990) Satellite tracking of wandering albatrosses. Nature 343:746-748

Jouventin P, Stahl JC, Weimerskirch H (1988) La conservation des oiseaux des Terres Australes et Antarctiques Françaises. In: ICPB (International Council for the Preservation of Birds) (ed) Livre rouge des oiseaux menacés d'outre-mer, Vol 5. Saint Cloud, p 226-251

Klomp NI, Schultz MA (1998) The remarkable foraging behaviour of short-tailed shearwaters breeding in eastern Australia. Ostrich 69:373-374

Marchant S, Higgins PJ (1990) Handbook of Australian, New Zealand and Antarctic birds. Oxford University Press, Melbourne

Miller DGM, Hampton I (1989) Biology and ecology of the Antarctic krill (Euphausia superba): a review. BIOMASS Scientific Ser 9:1-166

Miquel JC (1991) Distribution and abundance of post-larval krill (Euphausia superba Dana) near Prydz Bay in summer with reference to environmental conditions. Antarct Sci 3: 279-292

Mougin JL (1970) Le pétrel à menton blanc Procellaria aequinoctialis de l'île de la Possession (Archipel Crozet). L'oiseau et RFO 40:63-96

Murphy RC (1936) Oceanic birds of South America. Mac Millan, New York

Nicholls DG, Stampton P, Klomp NI, Schultz M (1998) Postbreeding flight to Antarctic waters by a short-tailed shearwater Puffinus tenuirostris. Emu 98:79-82

Pakhomov EA, MCQuaid CD (1996) Distribution of surface zooplankton and seabirds across the Southern Ocean Polar Biol 16:271-286

Park YH, Gamberoni L, Charriaud E (1993) Frontal stucture, water masses, and circulation in the Crozet Basin. J Geophys Res 12:361-385

Pequegnat LH (1965) The bathypelagic mysid Gnathophausia (Crustacea) and its distribution in the eastern Pacific Ocean. Pac Sci 19:399-421

Prince PA, Croxall IP, Trathan PN. Wood AG (1998) The pelagic distribution of South Georgia albatrosses and their relationships with fisheries. In: Robertson G, Gales R (eds) Albatross biology and conservation. Surrey Beatty \& Sons. Chipping Norton. p 137-167

Rand RW (1963) Seabirds in the southern Indian Ocean. Ostrich 34:121-128

Reynolds RW, Smith TM (1994) Improved global sea surface temperature analyses. J Cimate 7:929-948 
Ricklefs RE (1990) Seabird life histories and the marine environment: some speculations. Colon Waterbirds 13:1-79

Ridoux V (1989) Impact des oiseaux de mer sur les ressources marines autour des lles Crozet: estimation préliminaire. In: Laubier L (ed) Actes du colloque sur la recherche française dans les Terres Australes, Strasbourg, p 85-94

Ridoux $V(1994)$ The diets and dietary segregation of seabirds at the sub-Antarctic Crozet Islands. Mar Ornithol 22: $76-82$

Rodhouse PG, Prince PA, Trathan PN, Hatfield EMC, Watkins JL, Bone DG, Murphy EJ, White MG (1996) Cephalopods and mesoscale oceanography at the Antarctic polar front: satellite tracked predators locate pelagic trophic interactions. Mar Ecol Prog Ser 136:37-50

Roper CFE, Lu CC, Vecchione M (1998) A revision of the systematics and distribution of Illex species (Cephalopoda: Ommastrephidae). Smithson Contr Zool 586:405-423

Ryan PG, Boix-Hinzen C (1999) Consistent male-biased seabird mortality in the Patagonian toothfish long-line fishery. Auk 116:851-854

Ryan PG, Moloney CL (1988) Effect of trawling on bird and seal distributions in the Southern Benguela region. Mar Ecol Prog Ser 45:1-11

Sagar PM, Weimerskirch H (1996) Satellite tracking of southern Buller's albatrosses from the Snares, New Zealand. Condor 98:649-652

Schneider DC (1990) Seabirds and fronts: a brief overview. Polar Res 8:17-21

Smale MJ, Watson G, Hecht T (1995) Otolith atlas of Southern African marine fishes. Ichthyological Monographs, Vol 1. JLB Smith Institute of Ichthyology, Grahamistown

Stahl JC, Bartle JA, Jouventin P, Roux JP, Weimerskirch H (in press) Atlas of seabird distribution in the south-west Indian Ocean. Mar Ornithol

Vaske TJ (1991) Seabird mortality on longline fishing for tuna in Southern Brazil. Cienc Cult 43:388-390

Veit RR, Hunt GL (1991) Broadscale density and aggregation of pelagic birds from a circumpolar survey of the Antarctic Ocean. Auk 108:790-800

Warham J (1990) The petrels. Their ecology and breeding systems. Academic Press, London

Waugh SM, Weimerskirch $\mathrm{H}$, Cherel $\mathrm{Y}$, Shankar U, Prince PA, Sagar PM (1999) Exploitation of the marine environment by two sympatric albatrosses in the Pacific Southern Ocean. Mar Ecol Prog Ser 177:243-254

Weimerskirch $\mathrm{H}$ (1998a) Foraging strategies of Indian Ocean

Editorial responsibility: Otto Kinne (Editor),

Oldendorf/Luhe, Germany albatrosses and their relationships with fisheries. In Robertson G, Gales R (eds) Albatross biology and conservation. Surrey Beatty \& Sons, Chipping Norton, p 168-179

Weimerskirch $\mathrm{H}$ (1998b) How can a pelagic seabird provision its chick when relying on a distant food resource? Cyclic attendance, foraging decision and body condition in sooty shearwaters. J Anim Ecol 67:99-109

Weimerskirch $H$ (1999) The role of body condition in breeding and foraging decisions in albatrosses and petrels. In Adams NJ. Slotow RH (eds) Proc 22nd Int Ornithol Congr, Durban. Bird Life South Africa, Johannesburg, p 1178-1189

Weimerskirch H, Cherel Y (1998) Feeding ecology of shorttailed shearwaters: breeding in Tasmania and foraging in the Antarctic? Mar Ecol Prog Ser 167:261 -274

Weimerskirch H, Salamolard M, Sarrazin F, Jouventin P (1993) Foraging strategy of wandering albatrosses through the breeding season: a study using satellite telemetry. Auk 110:325-342

Weimerskirch $\mathrm{H}$, Chastel $\mathrm{O}$, Ackermann L, Chaurand $\mathrm{T}$ Cuénot-Chaillet F, Hindermeyer X, Judas J (1994) Alternate long and short foraging trips in pelagic seabird parents, Anjm Behav 47:472-476

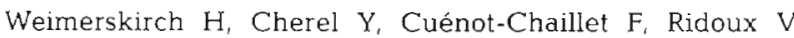
(1997a) Alternative foraging strategies and resource allocation by male and female wandering albatrosses. Ecology 78:2051-2063

Weimerskirch H. Mougey T, Hindermeyer X (1997b) Foraging and provisioning strategies of black-browed albatrosses in relation to the requirements of the chick: natural variation and experimental study. Behav Ecol 8:635-643

Weimerskirch $\mathrm{H}$, Catard $A$, Prince PA, Cherel $Y$, Croxall JP (1999a) Foraging white-chinned petrels Procellaria aequinoctialis at risk: from the tropics to Antarctica. Biol Conserv 87:273-275

Weimerskirch H, Fradet $G_{1}$ Cherel $Y$ (1999b) Natural and experimental changes in chick provisioning in a longlived seabird, the Antarctic prion. J Avian Biol 30:165-174

Whitehead PJP (1985) Clupeoid fishes of the world (Suborder Clupeoidei), Part 1. Chirocentridae, Clupeidae and Pristigasteridae. FAO Species Catalogue, Vol 7. FAO, Rome

Wilkinson L (1997) SYSTAT 7,0 for Windows. SPSS, Chicago

Wilson RP (1984) An improved stomach pump for penguins and other seabirds. J Field Orn 55:109-112

Woehler EJ, Hodges CL, Watts DJ (1990) An atlas of the pelagic distribution and abundance of seabirds in the southern Indian Ocean, 1981 to 1990. ANARE Res Notes 77

Submitted: June 24, 1999; Accepted: September 14, 1999

Proofs received from author(s): February 18, 2000 